\title{
Pengembangan Modul Deteksi Risiko Stunting Terhadap Pengetahuan Ibu Hamil
}

\author{
Development of Stunting Risk Detection Module on Pregnant Mother \\ Knowledge
}

\author{
Musdalifah $^{1}$, Esther Sanda Manapa ${ }^{2}$, Mardiana Ahmad ${ }^{3}$, Werna Nontji ${ }^{4}$, \\ Deviana Soraya Riu ${ }^{5}$, Healthy Hidayanti ${ }^{6}$ \\ ${ }^{1}$ Program Studi Ilmu Kebidanan Sekolah Pascasarjana, Universitas Hasanuddin \\ ${ }^{2}$ Lembaga Penjamin Mutu dan Pengembangan Pendidikan, Universitas Hasanuddin \\ ${ }^{3,4}$ Dosen Program Studi Ilmu Kebidanan, Universitas Hasanuddin \\ ${ }^{5}$ Dosen Fakultas Kedokteran Universitas Hasanuddin \\ ${ }^{6}$ Fakultas Kesehatan Masyarakat Universitas Hasanuddin \\ ${ }^{1}$ Email: Musdalifah@pasca.unhas.ac.id
}

\begin{abstract}
ABSTRAK
Stunting merupakan masalah gizi kronis yang berdampak tidak hanya pada segi kesehatan tapi mempengaruhi kecerdasan Salah satu strategi untuk mengatasi stunting yakni intervensi gizi pada ibu hamil untuk meningkatkan pengetahuan pada 1000 Hari Pertama Kehidupan dengan pemberian edukasi kepada ibu hamil. Penelitian ini bertujuan menghasilkan produk media edukasi berbentuk modul untuk mendeteksi risiko stunting yang diperuntukkan bagi ibu hamil. Penelitain pengembangan mengacu pada tahapan penelitian pengembangan Borg \& Gell. Tahap awal diawali dengan FGD dan studi pendahuluan, selanjutnya dilakukan uji kelayakan modul dan uji coba pengguna sampel kecil, lalu dilanjutkan dengan penelitian yang menggunakan Quasi Eksperimen (Pre-test post-test design). 30 orang ibu hamil yang berdomisili di wilayah kerja Puskesmas Cangadi dijadikan sampel dengan teknik purposive sampling. Hasil penelitian menunjukkan bahwa mayoritas responden yakni 82.5\% mengalami peningkatan pengetahuan hal ini menyatakan bahwa modul yang dikembangkan dapat meningkatkan pengetahuan ibu hamil.
\end{abstract}

Kata kunci: Stunting, Pengembangan Modul, Deteksi Risiko stunting, pengetahuan ibu hamil.

\section{ABSTRACT}

Stunting is a nutritional problem that affects only in terms of health but affects intelligence One strategy to overcome stunting is nutrition in pregnant women to increase knowledge in the First 1000 Days of Life by providing education for pregnant women. The purpose of this research was to develop educational media products in the form of modules to support the risk of stunting intended for pregnant women. Research development at the Borg \& Gell development research stage. The initial stage begins with a FGD and a preliminary study, then a module feasibility test and a small sample user trial are carried out, followed by a study using a Quasi Experiment (pre-test post-test design). 30 pregnant women domiciled in the working area of the Cangadi Community Health Center were sampled with a purposive sampling technique. The results showed that respondents gained $82.5 \%$ increased knowledge. This agreed that the module developed could increase the knowledge of pregnant women.

Keywords: Stunting, Development Module, Stunting Risk Detection, knowledge of pregnant women.

\section{PENDAHULUAN}

Stunting merupakan masalah

gizi kronis pada balita yang ditandai dengan tinggi badan yang lebih pendek dibandingkan dengan anak seusianya. Anak yang menderita stunting akan 
lebih rentan terhadap penyakit dan berisiko untuk mengidap penyakit degenerative, dampak stunting tidak hanya pada segi kesehatan tapi juga mempengaruhi kecerdasan (Kemenkes, 2018). Untuk penentu kejadian anak stunting di Indonesia intervensi yang paling berhasil yakni pengetahuan (Beal dan Neufeld, 2018). Dalam rangka pencegahan terjadinya stunting khususnya pada balita maka pemerintah melaksanakan Program Percepatan Perbaikan Gizi dengan Gerakan 1000 Hari Pertama Kehidupan (Ruaida, 2018).

Data prevalensi balita stunting yang dirilis World Health Organization $(W H O)$, bahwa Indonesia termasuk kedalam negara ketiga dengan prevalensi stunting tertinggi di regional Asia Tenggara Sout-East Asia Regional (SEAR). Dengan rata-rata $36.4 \%$ kasus stunting.(UNICEF, WHO, and Estimates, 2018) Proporsi status gizi pada Balita sangat pendek dan pendek di Indonesia tahun 2017 yakni 9.8\% dan $19.8 \%$ kondisi ini meningkat pada tahun 2018 yaitu 30.8\%,Balita stunting di Provinsi Sulawesi Selatan tahun 2017 yaitu $34.8 \%$ dan tahun $201835.6 \%$ (Riskesdas, 2018). Proporsi balita sangat pendek yaitu $6,5 \%$ dan balita pendek yaitu $10,4 \%$ hal ini terjadi peningkatan pada tahun 2018 yaitu $20.2 \%$ kejadian balita stunting (Dinkes Kabupaten Soppeng, 2017 dan 2018).

Penyebab terjadinya stunting adalah kurangnya pengetahuan tentang gizi sebelum dan masa kehamilan, masih terbatasnya layanan kesehatan termasuk layanan ANC (Ante Natal Care) kurangnya akses rumah tangga/keluarga ke makanan bergizi, kurangnya akses ke air bersih dan sanitasi (TNP2K, 2017). Kondisi kesehatan dan gizi sebelum dan saat kehamilan serta setelah persalinan mempengaruhi pertumbuhan dan risiko terjadinya stunting (Rohmawati dan Sulistiyani, 2019), stunting mulai terjadi ketika seorang remaja menjadi seorang ibu yang kurang gizi dan anemia, menjadi parah ketika hamil dengan asupan gizi yang tidak mencukupi kebutuhan, kondisi tersebut berdampak pada bayi yang dilahirkan (Kemenkes, 2018). Salah satu strategi untuk mengatasi stunting dan harus dilaksanakan yakni intervensi gizi pada ibu hamil untuk meningkatkan pengetahuan ibu pada 1000 Hari Pertama Kehidupan (1000 HPK) dengan pemberian edukasi berupa penyuluhan kepada ibu hamil (Kemenkes, 2018). 
Selama ini, dalam pemberian edukasi kepada ibu hamil, umumnya bidan menggunakan buku KIA, yang didalamnya memuat tentang pemantauan pertumbuhan dan perkembangan balita, khusus untuk deteksi risiko stunting tidak termuat dengan jelas, hal inilah yang diduga menjadi salah satu penyebab rendahnya pengetahuan ibu hamil akan stunting.

Hasil studi pendahuluan mendapati bahwa pengetahuan ibu hamil tentang stunting masih rendah yaitu sebesar $29.2 \%$ pada ibu hamil Kek dan $60.6 \%$ ibu hamil normal. Penelitian mendapati bahwa faktor risiko stunting dapat dicegah dengan meningkatkan pengetahuan dan intervensi dini kasus gizi (Nshimyiryo et al., 2019), Menggunakan kartu media integrating card bagi kader posyandu sebagai upaya promotif dan preventif untuk meningkatkan pengetahauan ibu untuk mendeteksi risiko stunting (Astuti et al, 2018).

$$
\text { Pemberian edukasi gizi }
$$
merupakan strategi untuk meningkatkan pengetahuan ibu-ibu di posyandu dengan pengembangan media poster (Hermina \& Prihatini, 2015) sejalan dengan penelitian (Wahyurin et al,
2019) menerapkan metode brainstorming dan audio visual dalam hal pemberian edukasi untuk mendeteksi risiko stunting.

Salah satu cara meningkatkan pengetahuan yaitu dengan penggunaan modul sehingga peneliti melakukan penelitian yang berjudul "Pengembangan Modul Deteksi Risiko Stunting terhadap pengetahuan ibu hamil di Puskesmas Cangadi di Kabupaten Soppeng”.

Tujuan penelitian ini yaitu menghasilkan suatu produk media edukasi berbentuk modul deteksi risiko stunting pada ibu hamil yang dapat meningkatkan pengetahuan ibu hamil. Langkah-langkah yang dilakukan dalam penelitian ini yaitu melakukan analisis kebutuhan produk media edukasi berbentuk modul, menyusun materi modul dan instrumen validasi, melakukan validasi modul deteksi risiko stunting pada ibu hamil dengan menggunakan ahli media dan ahli materi, melakukan validasi modul deteksi risiko stunting dengan pengguna langsung yakni ibu hamil serta melakukan pengujian efektifitas modul deteksi risiko stunting dalam meningkatkan pengetahuan ibu hamil. 


\section{METODE PENETIAN}

Jenis penelitian ini adalah penelitian (Research and Development) $R \quad \& \quad D$ yang merupakan metode penelitian yang digunakan untuk menghasilkan produk tertentu dan menguji keefektifan produk tersebut. Penelitian $R$ \& $D$ dilakukan melalui beberapa tahap menurut Borg dan Gall, yaitu 1) Analisa produk, 2) Pengembangan produk, 3) Validasi ahli media dan ahli materi, 4) Uji coba lapangan skala kecil) 5) Uji coba lapangan skala besar.

Langkah-langkah yang

dilakukan dalam pengembangan modul deteksi risiko stunting yaitu dengan melakukan Kegiatan FGD untuk mengumpulkan informasi atau data dari narasumber FGD yang terdiri dokter umum, bidan koordinator, bidan desa, petugas gizi, petugas Promkes, perawat, perwakilan kader dan ibu hamil yang berada di wilayah kerja tempat penelitian. Analisis kebutuhan tersebut dijadikan sebagai acuan dalam mengembangkan produk berbentuk modul. Selanjutnya dilakukan uji kelayakan modul dengan pemberian angket berupa : a. Angket Validasi Ahli Media

Angket yang digunakan adalah angket validasi modul yang diterbitkan oleh BNSP (Badan Standar Nasional Pendidikan). Aspek yang dinilai dalam angket validasi modul deteksi risiko stunting yaitu ukuran modul, desain modul, dan isi modul.

b. Angket validasi Ahli Materi .

Aspek yang dinilai dalam angket validasi modul deteksi risiko stunting pada kehamilan yaitu kelayakan isi, penyajian, bahasa, dan konstekstual.

c. Angket validasi pengguna

Angket diberikan perwakilan ibu hamil untuk mengetahui respon sebagai pengguna terhadap modul deteksi risiko stunting dengan indikator penilaian yaitu ketertarikan, materi, dan bahasa.

d. Kuesioner/Tes

Pertanyaan yang tercantum dalam tes telah dilakukan uji validasi dan realibitas dengan melibatkan $30 \mathrm{ibu}$ hamil. Tes ini berbentuk pertanyaan tertutup (benar salah) yang terdiri dari 15 pertanyaan. 
Penelitian pada sempel besar ini merupakan penelitian quasi eksperimental (one group pretest dan posttes design). Yang dilakukan pada bulan 27 Januari 2020 - 3 Fabruari 2020. Sampel dalam penelitian ini adalah ibu hamil yang berdomisili di wilayah Puskesmas Cangadi Kecamatan Liliriaja Kabupaten Soppeng. Pengambilan sampel menggunakan purposive sampling. Penelitian ini telah memperoleh Rekomendasi persetujuan etik yang dikeluarkan oleh komisi etik Universitas Hasanuddin.

\section{HASIL DAN PEMBAHASAN}

Tahapan awal pada penelitian ini yaitu pengembangan draft awal yang mencakup sebagai berikut:

1. Analisis produk yang akan dikembangkan

a. Merumuskan tujuan modul deteksi risiko stunting pada kehamilan
Tujuan modul ini adalah meningkatkan pengetahuan ibu hamil tentang:

1) Pengertian stunting

2) Faktor penyebab stunting

3) Dampak stunting

4) Pencegahan dan penanganan pada 1000 Hari Pertama Kehidupan

b. Menyiapkan dan menyusun bahan materi modul deteksi risiko stunting

Bahan/ materi yang disusun diperoleh melalui kajian pustaka dengan mengacu pada tujuan modul deteksi risiko stunting. Menyusun soal evaluasi dan lembaran skrining/ ceklist risiko stunting pada ibu hamil.

c. Menyusun alat evaluasi (instrumen validasi) untuk mengukur kelayakan dan efektifitas modul.

\section{Validasi Uji Ahli}

Tabel 1. Hasil uji komponen modul ahli materi deteksi risiko stunting.

\begin{tabular}{llccc}
\multicolumn{1}{c}{ KOMPONEN } & AHLI I & AHLI II & $\begin{array}{c}\text { RATA-RATA } \\
\text { PENILAIAN }\end{array}$ \\
\hline \multicolumn{1}{c}{ Aspek Kelayakan Isi } & & & $\mathbf{3 . 4 5}$ \\
$\mathbf{1}$ & Kesesuain materi & 3.2 & 3.7 & 3.60 \\
$\mathbf{2}$ & Keakuratan materi & 3.2 & 3.6 & 3.20 \\
$\mathbf{3}$ & Kemuktahiran Mmateri & 3.0 & 4.0 & 3.50 \\
\hline
\end{tabular}




\begin{tabular}{llccc}
\hline \multicolumn{1}{c}{ KOMPONEN } & AHLI I & AHLI II & $\begin{array}{c}\text { RATA-RATA } \\
\text { PENILAIAN }\end{array}$ \\
\hline $\mathbf{4}$ & Mendorong keingintahuan & 3.2 & 4.0 & 3.60 \\
& \multicolumn{1}{c}{ Aspek Kelayakan Penyajian } & $\mathbf{3 . 6}$ & $\mathbf{3 . 7}$ & $\mathbf{3 . 6 5}$ \\
$\mathbf{1}$ & Teknik penyajian & 3.0 & 3.0 & 3.00 \\
$\mathbf{2}$ & Pendukung penyajian & 3.4 & 3.8 & 3.60 \\
$\mathbf{3}$ & Penyajian pembelajaran & 4.0 & 4.0 & 4.00 \\
$\mathbf{4}$ & Koherensi dan keruntutan alur pikir & 4.0 & 4.0 & 4.00 \\
& Aspek Kelayakan Bahasa & $\mathbf{3 . 5 6}$ & $\mathbf{3 . 2}$ & $\mathbf{3 . 3 8}$ \\
$\mathbf{1}$ & Lugas & 3.3 & 3.0 & 3.15 \\
$\mathbf{2}$ & Komunikatif & 3.0 & 3.0 & 3.00 \\
$\mathbf{3}$ & Diagnosis dan interaktif & 4.0 & 4.0 & 4.00 \\
$\mathbf{4}$ & Kesesuaian dengan perkembangan & 4.0 & 3.0 & 3.50 \\
$\mathbf{5}$ & Kesesuaian dengan kaidah bahasa & 3.5 & 3.0 & 3.25 \\
& $\quad$ Aspek Kelayakan Konstektual & $\mathbf{3 . 8}$ & $\mathbf{3 . 8}$ & $\mathbf{3 . 8}$ \\
$\mathbf{1}$ & Hakikat konstektual & 3.5 & 3.5 & 3.50 \\
$\mathbf{2}$ & Komponen konstektual & 4.0 & 4.0 & 4.00 \\
& $\quad$ RATA-RATA & & & $\mathbf{3 . 5 7}$ \\
& $\quad$ & & & (sangat baik) \\
\hline
\end{tabular}

\begin{tabular}{lll}
\multicolumn{2}{r}{ Sehubungan } & \multicolumn{2}{c}{ pemaparan } & termasuk kategori sangat baik hal \\
hasil uji ahli materi diatas & ini dapat dilihat rata- rata \\
menyatakan bahwa kualitas dan & persentase keempat aspek \\
kelayakan modul deteksi risiko & komponen modul deteksi risiko \\
stunting yang dikembangkan & stunting yaitu 3.57\%.
\end{tabular}

Tabel 2. Hasil Uji Ahli Media Komponen Modul Deteksi Risiko Stunting.

\begin{tabular}{llccc}
\hline \multicolumn{1}{c}{ KOMPONEN } & AHLI I & AHLI II & $\begin{array}{c}\text { RATA-RATA } \\
\text { PENILAIAN }\end{array}$ \\
& Ukuran Modul & & & $\mathbf{3 . 0}$ \\
$\mathbf{1}$ & Kesesuain ukuran modul dengan standar ISO & 3.0 & 3.0 & 3.0 \\
$\mathbf{2}$ & Kesesuaian ukuran dengan materi isi modul & 3.0 & 3.0 & 3.0 \\
& $\quad$ Desain Sampul (Cover) & $\mathbf{2 7 3 . 3}$ & $\mathbf{3 . 0}$ & $\mathbf{3 . 2}$ \\
$\mathbf{3}$ & Penampilan unsur tata letak & 3.0 & 3.0 & 3.0 \\
$\mathbf{4}$ & Warna unsur tata letak & 4.0 & 3.0 & 3.5 \\
$\mathbf{5}$ & Huruf yang digunakan menarik dan muda dibaca & 3.3 & 3.0 & 3.2 \\
$\mathbf{6}$ & Ilustrasi sampul modul & 3.0 & 3.0 & 3.0 \\
& $\quad$ Desain Isi Modul & $\mathbf{3 . 3}$ & $\mathbf{2 . 9}$ & $\mathbf{3 . 1 0}$ \\
$\mathbf{7}$ & Konsistensi tata letak penampilan & 3.5 & 2.5 & 3.00 \\
$\mathbf{8}$ & Unsur tata letak bidang cetak dan spasi & 3.5 & 3.0 & 3.25 \\
$\mathbf{9}$ & Unsur tata letak judul dan ilustrasi & 3.5 & 3.0 & 3.25 \\
$\mathbf{1 0}$ & Tata letak $\quad 3.0$ & 3.0 & 3.00 \\
$\mathbf{1 1}$ & Tipografi isi modul sederhana & 3.7 & 2.7 & 3.20 \\
$\mathbf{1 2}$ & Tipografi isi modul memudahkan & 3.0 & 3.0 & 3.00 \\
\hline
\end{tabular}




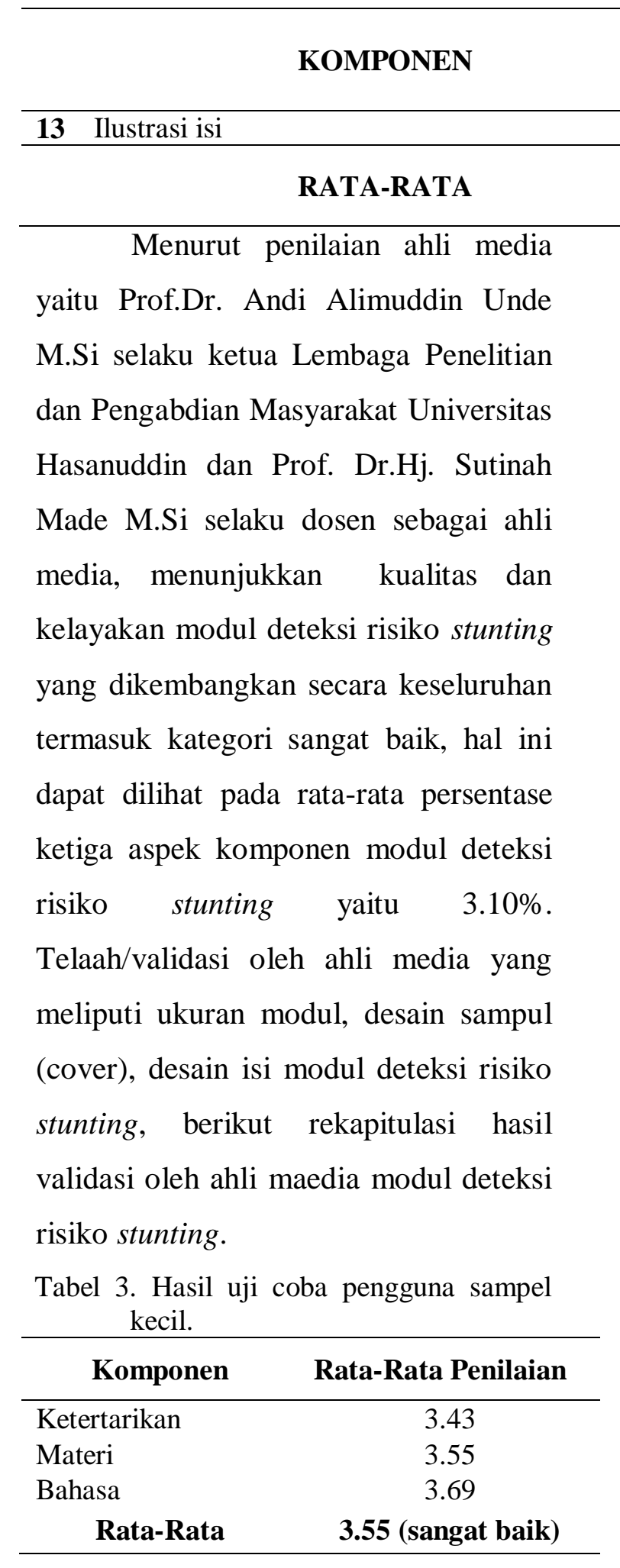

Menurut penilaian 10 pengguna sampel kecil pada tabel 3 menunjukkan kualitas dan kelayakan modul deteksi

AHLI I AHLI II RATA-RATA PENILAIAN

$\begin{array}{lll}3.0 & 3.0 & 3.00\end{array}$

(Sangat baik)

risiko stunting yang dikembangkan secara keseluruhan termasuk kategori sangat baik, hal ini dapat dilihat pada rata-rata persentase ketiga aspek komponen modul deteksi risiko stunting yaitu $3.55 \%$.

3. Uji efektifitas modul deteksi risiko stunting.

Penyajian data efektifitas modul deteksi risiko stunting dapat dilihat dari hasil pretest dan posttest 30 ibu hamil, untuk mengetahui peningkatan hasil setelah diberikan intervensi. Berikut hasil rekapitulasi pretest dan post test.

Tabel 4. Rekapitulasi skor rata -rata pre test dan post test

\begin{tabular}{cc}
\hline \multicolumn{1}{c}{ Tahap } & Nilai Rata-rata \\
\hline Pre test & 56.60 \\
Post test & 84.50 \\
Peningkatan & 27.90 \\
Persentase & $\mathbf{4 9 . 2 9 \%}$ \\
Peningkatan & \\
\hline
\end{tabular}

Berdasarkan tabel 4 hasil tes awal (pretest) $56.60 \%$ sedangkan nilai hasil post test yakni $84.50 \%$ jadi peningkatan hasil yakni $27.90 \%$ menunjukkan bahwa modul deteksi risiko stunting yang dikembangkan dapat meningkatkan pengetahuan ibu 
hamil dan jika dipersentasikan terjadi peningkatan $49.29 \%$.

Selanjutnya melakukan uji signifikan perbedaan rata rata hasil pretest dan post test yang didapatkan diuji dengan menggunakan uji Wilcoxon :

Tabel 5. Hasil Analisis pre test dan post test modul deteksi risiko stunting.

\begin{tabular}{llccc}
\hline & N & $\begin{array}{c}\text { Mean } \\
\text { Rank }\end{array}$ & $\begin{array}{c}\text { Sum } \\
\text { of } \\
\text { Ranks }\end{array}$ \\
\hline \multirow{4}{*}{$\begin{array}{l}\text { Posttest } \\
\text {-Pretest }\end{array}$} & $\begin{array}{l}\text { Neganks } \\
\text { Ranks }\end{array}$ & $0^{\mathrm{a}}$ & 0.00 & 0.00 \\
& $\begin{array}{l}\text { Psitive } \\
\text { Ranks }\end{array}$ & $30^{\mathrm{b}}$ & 15.50 & 465.00 \\
& Ties & $0^{\mathrm{c}}$ & & \\
& Total & $\mathbf{3 0}$ & & \\
\hline
\end{tabular}

Uji Wilcoxon Signed Rank Test

Hasil Uji Wilcoxon

menunjukkan positive ranks yang mengindikasikan bahwa seluruh responden mendapatkan peningkatan pengetahuan setelah diberikan intervensi.

Penelitian pengembangan modul deteksi risiko stunting diawali dengan Focus Group Discussion (FGD) dan studi pendahuluan, dari hasil FGD dikembangkan sebuah produk berupa modul deteksi risiko stunting di peruntukkan bagi ibu hamil, materi yang disajikan pada modul ini berupa pengetahuan tentang stunting, faktor penyebab stunting, dampak stunting dan pencegahan penanganan 1000 Hari
Pertama kehidupan. Setiap materi ada penjelasan dan illustrasi untuk memperjelas setiap isi materi, sehingga tidak membosankan pembaca, pada akhir modul dilengkapi dengan kesimpulan, soal-soal latihan dan kunci jawaban, skrining cek list deteksi risiko stunting pada ibu hamil, sehingga memudahkan ibu hamil memahami materi dan mendeteksi dini faktor risiko penyebab stunting, hal ini sejalan dengan penelitian pengembangan dalam hal ini untuk mendeteksi dini stunting yang diperuntukkan bagi kader posyandu (Isnar dan Alfiah, 2019) dikembangkan pula modul peduli ibu hamil yang diperuntukkan bagi ibu hamil untuk meningkatkan pengetahuan ibu hamil seputar informasi tentang kehamilan (Ningsih, 2020) selain itu pengembangan modul 1000 Hari Pertama Kehidupan bertujuan menghasilkan produk berupa modul yang diperuntukkan bagi kader Bina Keluarga Kelompok Balita (Nurhayati, 2019). Terkait dengan deteksi kehamilan risiko tinggi diperlukan pengembangan manual rujukan KIA dalam hal ini bidan berperan sebagai gate keeper bagi ibu hamil yang memerlukan tindakan lanjutan (Nova Elok Mardliyana, 2019) salah satu 
fungsi modul yakni media modul yang dicetak dengan kemasan menarik dan perhatian pembaca berkonstrasi pada isi materi yang tertulis di dalamnya (Sulistiyani, dkk 2013) sebelum diaplikasikan modul di validasi oleh ahli, untuk validasi ahli materi memuat komponen aspek kelayakan isi, aspek kelayakan penyajian, aspek kelayakan bahasa, aspek kelayakan konsektual hasil rata-rata yakni $3.57 \%$ hal ini berarti bahwa kelayakan dan kualitas modul sangat baik.

Modul merupakan seperangkat bahan ajar yang dikemas secara utuh dan sistematis, didalamnya memuat seperangkat pengalaman belajar yang terencana dan didesain untuk mencapai tujuan belajar yang spesifik (Daryanto,2013) modul dapat diplejari setiap waktu, modul sebaiknya di buat sedikit bervariasi agar mengurangi kejenuhan Sulistiyani dkk (2013), modul dicetak dengan ukuran kecil agar lebih efisien, praktis dan mudah menggunakanya. Gambar pada modul ini disajikan sesuai dengan kajian permasing masing masing materi oleh karena gambar yang disajikan merupakan daya tarik utama (Arsyad, 2011) menyatakan bahwa ukuran yang relatif kecil dan memuat berbagai gambar-gambar merupakan kertarikan tersendiri untuk kategori modul. Dari ke dua ahli media masing masing menilai komponen modul yakni aspek ukuran modul, desain sampul (cover), desain isi modul. Berdasarkan hasil validasi diperoleh rata rata nilai $3.10 \%$ hal ini menujukkan bahwa kualitas dan kelayakan modul sangat baik, untuk pengguna sampel kecil yakni $10 \mathrm{ibu}$ hamil berdasarkan komponen modul dari aspek ketertarikan, materi, bahasa, memperoleh rata rata nilai $3.55 \%$ hal ini menunjukkan sangat baik.

Pengetahuan ibu hamil terhadap modul deteksi risiko stunting.

Terkait dengan hal ini untuk meningkatkan pengetahuan ibu hamil tentang deteksi risiko stunting pada khususnya diperlukan modul sebagai media edukasi, hasil dari beberapa penelitian menyatakan modul efektif meningkatkan pengetahuan. (Daryanto, 2013) mendifinisikan bahwa modul adalah sebagai bahan ajar mandiri yang dirancang secara sistematis terarah, dan terukur untuk mencapai tujuan pembelajaran dalam hal ini modul berperan meningkatkan pengetahuan dan minat peserta didik (Kholisho Nur Yosi, 2017). Modul kesehatan dan gizi diterapkan juga pada kegiatan 
Pertemuan Kemampuan Keluarga (Kemenkes, 2018) hal ini bertujuan untuk meningkatkan perubahan perilaku kesehatan ibu ibu penerima manfaat Program Keluarga Harapan dengan modul dapat meningkatkan pengetahuan terutama pentingnya 1000 Hari Pertama Kehidupan, kesehatan dan gizi ibu hamil, nifas, dan menyusui, bayi, dan balita serta peningkatan pola asuh, didapati pula modul berbasis keluarga juga dapat meningkatkan pengetahuan dan keterampilan pola asuh.(Jazariyah, 2017) Didapati pula penelitian mengatakan bahwa pengetahuan seseorang juga dipengaruhi oleh pendidikan usia dan akses terhadap media yang digunakan yakni pengaruh penyuluhan 1000 Hari Pertama Kehidupan kepada Pasangan Usia subur secara signifikan dapat meningkatkan pengetahuan dan pemahaman tentang 1000 Hari Pertama Kehidupan (Rakhmayu et al., 2019). Upaya preventif terhadap prevalensi stunting yakni dengan metode mind mapping, hal ini dapat meningkatkan pengetahuan dan wawasan (Ayu Budi Pratiwi et al, 2019).

Dari hasil pre test dan post test mengalami peningkatan yang signifikan setelah modul diberikan, begitupun juga cek list deteksi risiko stunting ibu hamil dapat mendeteksi risko sesuai yang dialami, hal ini dapat dilihat disetiap modul ibu hamil melakukan cek list deteksi risiko stunting, apabilaan ibu hamil memiliki risiko pada kehamilanya segera ke bidan atau petugas kesehatan yang terdekat terkait dengan faktor risiko penyebab stunting.

Adapun implikasi dari penelitian ini adalah memudahkan ibu hamil dalam mempelajari modul deteksi risiko stunting, karena modul ini dapat digunakan kapan saja, dimana saja dan oleh siapa saja dan modul deteksi risiko stunting ini dilengkapi denga skrinning cek list deteksi risiko stunting dalam hal ini ibu hamil dapat mendeteksi dini kehamilanya sehingga dapat dideteksi sedini mungkin dengan deteksi dini pada kehamilan dapat mencegah terjadinya stunting.

\section{SIMPULAN DAN SARAN}

Berdasarkan hasil penelitian dan analisa data yang dilakukan oleh peneliti maka dapat ditarik kesimpulan bahwa Modul deteksi risiko stunting sebagai media edukasi pada ibu hamil sangat layak untuk digunakan dan dapat memberikan dampak yang baik dalam 
mencegah stunting dengan peningkatan kemampuan dan pengetahuan ibu.

\section{DAFTAR PUSTAKA}

Adistie, F., Belinda, V., Lumbantobing, M., Nur, N., \& Maryam, A. (n.d.). Pemberdayaan Kader Kesehatan Dalam Deteksi Dini Stunting dan Stimulasi Tumbuh Kembang pada Balita. 1(2), 173-184.

Arsyati, A. M. (2019). Pengaruh Penyuluhan Media Audiovisual Dalam Pengetahuan Pencegahan Stunting Pada Ibu Hamil Di Desa Cibatok 2 Cibungbulang Pendahuluan. 2(3), 182-190.

Aryastmi, N. K., \& Tarigan, I. (2017). Kajian Kebijakan dan Penanggulangan Masalah Gizi Stunting di Indonesia. 233-240.

Astuti, S., Megawati, G., \& Samson. (2018). Promotive Efforts To Improve The Knowledge Of Mother Of Toddlers About.

Beal, T., \& Neufeld, L. M. (2018). Sebuah tinjauan penentu stunting anak di Indonesia (Maternal \& Child Nutrition). 1-10. https://doi.org/10.1111/mcn.12617

Benyamin S Bloom. (1981). Taxonomi of Education Objektives,The Calssification Education Goals:Handbook Cognitive Domine, .

Daryanto. (2013). Menyusun Modul (Bahan ajar untuk Persiapan dalam mengajar) (S. Darmiatun, Ed.). Jogyakarta: Penerbit Gava Media.

Depkes. (2015). Petunjuk teknis penggunaan Buku Keseahatan Ibu dan Anak.
Depkes 2010. (2010). Pedoman pemantauan wilayah setempat kesehatan ibu dan anak (pws-kia).

Fajar, I., Amala, S. R., \& Agistin, I. M. (2018). Penerapan model keluarga dengan pola hidup standar who dalam rangka penanganan. 2(1), 13-17.

Germas, K. (2019). Intervensi perubahan perilaku kesehatan keluarga dalam rangka pencegahan stunting.

Hanum, R., \& Safitri, M. E. (2018). Hubungan Pengetahuan Dan Sikap Ibu Hamil Tentang Pemanfaatan Buku Kia Di Puskesmas Namu Ukur. 1(3).

Hendarto, P., \& Prayitno, B. A. (2018). Keefektifan Modul Berbasis Guided Inquiry dilengkapi Komik terhadap Kemampuan Berargumentasi ditinjau dari Minat Baca Siswa. (1), 1652-1663.

Hermina, \& Prihatini, S. (2015). Pengembangan Media Poster dan Strategi Edukasi Gizi untuk Pengguna Posyandu dan Calon Pengantin. Buletin Penelitian Kesehatan, 43(3), 195-206.

Hiwot, E., Eshete, H., Abebe, Y., Loha, E., Gebru, T., \& Tesheme, T. (n.d.). Nutritional Status and Effect of Maternal Employment among Children Aged 6 - 59 Months in Wolayta Sodo Town, Southern Ethiopia : A Cross-sectional Study.

Isnar, S., \& Alfiah, N. (2019). Pengembangan Modul Deteksi Dini Pemantauan Balita Stunting Di Posyandu Samuel.

Jannatin, Ardhuha, Doyan, A., \& Susilawati. (2019). Pengembangan 
Modul Ajar Pada Mata Kuliah Pendahuluan Fisika Zat Padat Untuk Meningkatkan Penguasaan Konsep Struktur Kristal Bagi Calon Guru. Jurnal Pendidikan Fisika Dan Teknologi, 5(1).

Jazariyah. (2017). Pengembangan Modul Paud Berbasis Keluarga Untuk Peningkatan Ketrampilan Pengasuhan Di Kelompok Bermain Amanah Bunda.

Kemenkes. (2014). Pedoman Pelaksanaan Kelas Ibu Hamil. Jakarta: Kementerian Kesehatan RI: Katalog Dalam Terbitan (KDT).

Kemenkes. (2016). Pedoman Pelaksanaan: Stimulasi, Intervensi dini tumbuh kembang anak. Jakarta: Kemenkes RI.

Kemenkes. (2018). Modul Kesehatan \& Gizi Pertemuan Peningkatan Kemampuan Keluarga (P2K2) Program Keluarga Harapan (PKH) Panduan Teknis Pelaksanaan P2K2.

Kemenkes. (2018). Situasi Balita Pendek (Stunting)Di Indonesia Pusat Data dan Informasi , Kemenkes RI.

Margawati, A., \& Astuti, A. M. (2018). Pengetahuan ibu, pola makan dan status gizi pada anak stunting usia 1-5 tahun di Kelurahan Bangetayu , Kecamatan Genuk, Semarang. 6(2), 82-89.

Masrul. (2019). Profil kepemilikan dan tingkat pengetahuan ibu ibu tentang buku kia di padang Kabupaten Padang Pariaman. 42(2), 50-55. https://doi.org/10.25077/mka.v42.i 2.p50-55.2019
Menrisal, Yunus, Y., \& Rahmadini, N. S. (2019). perancangan dan pembuatan modul pembelajaran elektronisk bebasis project based learning mata pelajaran simualsi digital smkn 8 padang. Jurnal Koulutus, 2, 1-16.

Musfiroh, M., \& Beny Lukmanawati Wisudaningtyas. (2014). Penyuluhan terhadap sikap ibu dalam memberikan toilet training pada anak. 9(2), 157-166.

Mushtaq, M. U., Gull, S., Khurshid, U., Shahid, U., \& Shad, M. A. (2011). Prevalence and socio-demographic correlates of stunting and thinness among Pakistani primary school children Prevalence and sociodemographic correlates of stunting and thinness among Pakistani primary school children. 790 (October).

Naim, R., Juniarti, N., \& Yamin, A. (2016). Pengaruh Edukasi Berbasis Keluarga terhadap Intensi Ibu Hamil untuk Optimalisasi Nutrisi pada 1000 Hari Pertama Kehidupan Effect Of Family-Based Education Towards Pregnant Mothers 'Intention to Optimize The Nutrition at 1000 First Day Of Life. 5.

Notoatmojo, S. (2014). Ilmu Perilaku Kesehatan. Jakarta: Rineka Cipta.

Nshimyiryo, A., Bethany, G. H., Christine, M., M, K. C., Kathryn, B., Ndayisaba albert, ... Ziad, E.K. (2019). Faktor risiko stunting pada anak-anak di bawah lima tahun: cross-sectional studi berbasis populasi di Rwanda menggunakan Survei Demografi dan Kesehatan 2015. 1-10.

Nurhayati, Y. (2019). Pengembangan 
Modul Ceatak 1000 Hari Pertama Kehidupan Untuk Pelatihan Kader Bina Keluarga Balita DI BKKBN. 14(1).

Ningsih, D. A., 2020. Pengembangan Modul "Peduli Ibu Hamil" Di Desa Sumberejo Banyuputih Situbondo. JOMIS (Journal of Midwifery Science), 4(1), pp. 55-62.

Pengaruh Kelas Ibu Hamil Terhadap Peningkatan Pengetahuan Tentang Antenatal Care Pada Ibu Hamil Dengan Menggunakan Pendekatan Model Community As Partner Di Dusun Karangasem Desa Glagahwero Kecamatan Panti Kabupaten Jember. (2019). 2. https://doi.org/p-SN: 2620-6277, eISSN: 2620-6285

Pratama, I. S., Aini, S. R., \& Maharani, B. F. (2019). Implementasi Gasing (Gerakan Anti Stunting) Melalui Phbs Dan Pemeriksaan Cacing. 2(1), 80-83.

Puspitasari, A. D. (2019). Penerapan Media Pembelajaran Fisika Menggunakan Modul. Jurnal Pendidikan Fisika, 7(1), 17-25. Retrieved from http://journal.uinalauddin.ac.id/indeks.php/Pendidik anFisika\%0Ap-ISSN

Putri, B. gunawan, \& Astustik, T. (2018). ( The Effect Of Pregnancy Class On Pregnant Womans Knowledge about antenatal care using comunity as partner approach in the karang asem hamlet glagah wero village distric panti of jember regency. 10(September), 145-150.

Rafiq, R., Kishawi, E., Soo, K. L., Awad, Y., Abdul, W., \& Wan, M. (2017). Prevalensi dan terkait faktor yang mempengaruhi stunting pada anak usia 2 - 5 tahun di Jalur Gaza-Palestina: sebuah studi cross-sectional. 1-7.

Rahmawati, Rezal, F., \& Erawan, putu E. meiyana. (2017). Pengaruh Konseling Gizi Dengan Media Booklet Terhadap Peningkatan Pengetahuan,Sikap Dan Tindakan Dalam Upaya Pengesahan Gizi Buruk Baliat Diwilayah Kerja Puskesmas Puuwatu Kota Kendari Tahun 2017. 2(6), 1-12.

Rakhmahayu, A., Lanti, Y., Dewi, R., \& Murti, B. (2019). Logistic Regression Analysis on the Determinants of Stunting among Children Aged 6-24 Months in Purworejo Regency, Central Java. 4(3), 158-169.

Riskesdas. (2018). Hasil Utama RISKESDAS 2018. RISKESDAS.

Rohmawati, W. B. M. N., \& Sulistiyani, S. (2019). Faktor yang berhubungan dengan kejadian stunting pada balita di Desa Panduman Kecamatan Jelbuk Kabupaten Jember Risk factor of stunting among under five children in Panduman Village, Jelbuk SubDistrict , Jember Regency Hasil survei Pemantauan Status Gi. 02(02), 89-100.

Ruaida, N. (2018). Gerakan 1000 Hari Pertama Kehidupan Mencegah terjadinya stunting ( Gizi Pendek) di Indonesia. 3(2), 139-151.

Sastroasmoro, S. (2014). Dasar-dasar Metodologi Penelitian Klinis (Edisi ke-5). Jakarta.

Setyowati, H., Sofyanti, I., \& Widayanti, H. (2018). Penyusunan Media Informasi Tentang Praktik Pemberian Makan Untuk 
mencegah stunting pada anak Baduta. 1(September), 111-119.

Soppeng, K. D. K. (n.d.). Laporan Kesehatan Ibu dan Anak.

Statistik, B. P. (2014). Kajian Indikator Sustainable Development Goals ( SDGs ).

Sugiyono. (2017). Metode Penelitian Kebijakan (S. Y. Ratri, Ed.). Bandung.

TNP2K. (2017). 100 Kabupaten /Kota Prioritas Untuk Intervensi Anak kerdil (Stunting).

Unicef. (2015). Pendekatan UNICEF untuk scaling up pemrograman nutrisi untuk ibu dan anak-anak mereka.

UNICEF,WHO, \& Estimates, W. B. G. J. C. M. (2018). Levels and Trends in Child Malnutrition. 1-16.

Wahyurin, izka sofiyya, Aqmarina, A. nur, Rahmah, hiya alfi, Hasanah, ade uswatun, \& Silaen, christy nataly B. (2019). Pengaruh Edukasi Stunting Menggunakan Metode Brainstorming dan Audiovisual Terhadap Pengetahuan Ibu dengan Anak Stunting. 02(02), 141-146. 